\title{
Population genetic structure and demographic history of the spadefish, Chaetodipterus faber (Ephippidae) from Southwestern Atlantic
}

\author{
Leonardo Francisco Machado a,e,*, Junio de Souza Damasceno b,d, Áthila Andrade Bertoncini ${ }^{\mathrm{c}}$, \\ Vander Calmon Tosta ${ }^{a}$, Ana Paula Cazerta Farro ${ }^{a}$, Maurício Hostim-Silva ${ }^{a}$, Claudio Oliveira ${ }^{\mathrm{e}}$ \\ a Universidade Federal do Espírito Santo, PPGBT/DCAB/CEUNES, Rodovia BR 101 Norte, Km. 60, Bairro Litorâneo, 29932-540 São Mateus, Espírito Santo, Brazil \\ b Universidade Federal do Espírito Santo, PPGOAM/DOC/CCHN, Base Oceanográfica (UFES), Caixa Postal 2030, Coqueiral, 29199-970 Aracruz, Espírito Santo, Brazil \\ c Universidade Federal do Estado do Rio de Janeiro, LICTA, Av. Pasteur 458, Urca, 22290-240 Rio de Janeiro, Rio de Janeiro, Brazil

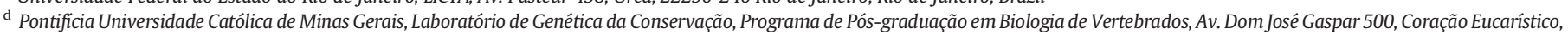 \\ 30535-901, Belo Horizonte, MG, Brazil \\ e Universidade Estadual Paulista, Instituto de Biociências, Dept. Morfologia, 18618-970 Botucatu, São Paulo, Brazil
}

\section{A R T I C L E I N F O}

\section{Article history:}

Received 15 October 2015

Received in revised form 1 November 2016

Accepted 3 November 2016

Available online 24 November 2016

\section{Keywords:}

Population genetics

Reef fishes

D-loop

COI

Haplotypes

SW Atlantic

\begin{abstract}
A B S T R A C T
Genetic diversity, population structure and demographic history of Chaetodipterus faber in SW Atlantic were investigated using mitochondrial DNA cytochrome c oxidase subunit I (620 bp) and D-loop ( $817 \mathrm{bp}$ ) sequences. Individuals were collected in five sampling units (SUs) located in latitudes between $2^{\circ} \mathrm{S}$ and $27^{\circ} \mathrm{S}$, southernmost limit of species distribution. The COI sequences from Brazilian sampling units were compared with eight sequences from the Gulf of Mexico and Caribbean, resulting in no significant genetic differences (K2P $<0.32 \%)$. On the contrary, pairwise $\mathrm{F}_{\mathrm{ST}}$ analysis based on D-loop datasets from the five SUs indicated divergence between Tropical and Subtropical clades of SW Atlantic C. faber. The SAMOVA approach was consistent with this divergence and revealed maximal variance among groups (63.59\%) when two clades are simulated $(\mathrm{k}=2)$, setting apart Tropical and Subtropical SUs. Demographic analyses support the hypothesis of population expansion, both for Tropical and Subtropical clades. Moreover, Subtropical population size increase was dated after the Tropical clade reached the demographic stability, around $10 \mathrm{kyr}$ ago, during the beginning of interglacial PleistoceneHolocene transition. The historical demographic results, along with the lower genetic diversity and the starshaped haplotype network of the Subtropical clade corroborate an ancient scenario of the species' adaptive radiation southward.
\end{abstract}

(c) 2016 Elsevier B.V. All rights reserved.

\section{Introduction}

Due to lack of visible barriers in the marine realm and the presumed ability of larvae to passively disperse over large distances, for decades, the prevailing paradigm was that marine fish populations mixed freely and had high levels of connectivity throughout their ranges (Morrison and Sandin, 2011). However, studies have shown that marine species are not uniformly distributed and in most species, populations are often subdivided into smaller units, due to geographic, ecological or behavioral factors (Hedrick, 2009).

Understanding population genetic structure has been an important tool for both fisheries management and conservation programs (Okumuş and Çiftci, 2003; Rocha et al., 2007; Schunter et al., 2011).

\footnotetext{
* Corresponding author at: Universidade Federal do Espírito Santo, PPGBT/DCAB/ CEUNES, Rodovia BR 101 Norte, Km. 60, Bairro Litorâneo, 29932-540 São Mateus, Espírito Santo, Brazil.

E-mail address: machado.fish@gmail.com (L.F. Machado).
}

The marine population structure approach is complex, but in spite of the emerging next generation sequencing methods, traditional single locus mtDNA studies continue to provide powerful first-assessment of phylogeographic patterns (Bowen et al., 2014; Clarke et al., 2015). The use of mtDNA markers has revealed historical and present-day barriers to gene flow in widespread marine species that were formerly believed to be homogeneous (Stepien et al., 2001; Rocha et al., 2005; Santos et al., 2006; Hubert et al., 2012).

The Atlantic spadefish Chaetodipterus faber (Broussonet, 1782), the single Ephippidae species in the western Atlantic, is a widespread species, occurring from Massachusetts to south Brazil, including the Gulf of Mexico and the Caribbean (Burgess, 2002; Hostim-Silva et al., 2006). Fisheries of $C$. faber in SW Atlantic reported by the Brazilian government reached an average annual catch of 258 tons (IBAMA, 2003, 2004a, 2004b, 2005, 2007a, 2007b, 2008; MPA, 2012a, 2012b, 2012c), from 2001 to 2011. Nonetheless, $C$. faber catches might be larger than informed, because the species is relatively common in artisanal, recreational and sport fisheries, which are difficult to quantify and sometimes 
not considered in fisheries reports (Böhlke and Chaplin, 1993; Pinheiro et al., 2010; Piorski et al., 2009; Ramires et al., 2012; Rangely et al., 2010)

Although it is known that it inhabits a variety of different habitats along shallow coastal waters, including mangroves, salt marshes, sandy beaches, harbors, piers, shipwrecks and offshore reefs (Burgess, 2002; Robins and Ray, 1986), many aspects of the biology and ecology of $C$. faber are still poorly studied (Barros et al., 2013; Bittencourt, 1990; Ditty et al., 1994; Hayse, 1990; Trushenski et al., 2012).

The present study comprises the first population genetics assessment of $C$. faber. The genetic connectivity among populations comprising more than $4000 \mathrm{~km}$ of the SW Atlantic coast (i.e. from the equator to southern limit of the species distribution) was evaluated providing a comprehensive approach of its genetic variability, population structure and demographic history.

\section{Material and methods}

\subsection{Sampling and DNA extractions}

Samples ( $\mathrm{n}=123$ ) were taken from fin tissues of $C$. faber collected at five sampling units (SUs) distributed along the Brazilian coast between the states of Maranhão (Lat. $2^{\circ} \mathrm{S}$ ) and Santa Catarina (Lat $27^{\circ} \mathrm{S}$; Fig. 1).

Specimens were obtained through spear fishing and from fishery landings in each region. Samples from fin tissue were placed in $1.5 \mathrm{~mL}$ tubes and preserved in 95\% ethanol. DNA extraction was performed following the saline extraction protocol described by Aljanabi and Martinez (1997).

In addition to the collected and sequenced samples (Table 1), a total of 26 cytochrome c oxidase subunit I (COI) sequences, available at the Barcode of Life Data System (BOLD; Ratnasingham and Hebert, 2007), from the Gulf of Mexico $(\mathrm{n}=1)$, Caribbean $(\mathrm{n}=7)$ and Brazil $(\mathrm{n}=$ 18), were also included.

\subsection{PCR amplifications and sequencing}

\subsubsection{Cytochrome c oxidase subunit I}

Partial COI sequences were isolated and amplified with the primers FishF2: 5'TCGACTAATCATAAAGATATCGGCAC3' and FishR2: 5'ACTT CAGGGTGACCGAAGAATCAGAA3' (Ward et al., 2005). PCR reactions
Table 1

Number of mitochondrial gene sequences of Chaetodipterus faber analyzed from each geographic region (refer to Fig. 1).

\begin{tabular}{llll}
\hline Sampling units & Localities & COI & D-loop \\
\hline GM & Gulf of Mexico & $1^{\text {a }}$ & - \\
CB & Caribbean & $7^{\text {a }}$ & - \\
SU1 & MA & 21 & 29 \\
SU2 & PB and PE & 12 & 12 \\
SU3 & ES: South Abrolhos Bank & $21\left(18^{\mathrm{a}}+3\right)$ & 30 \\
SU4 & RJ and SP & 21 & 24 \\
SU5 & SC & 21 & 28 \\
\hline
\end{tabular}

GM: Gulf of Mexico; CB: Caribbean; SU: Sampling unit. Brazilian States: MA: Maranhão; PB: Paraíba; PE: Pernambuco; ES: Espírito Santo; RJ: Rio de Janeiro; SP: São Paulo; SC: Santa Catarina. COI: cytochrome c oxidase subunit I; D-loop.

a BOLD sequences.

for amplification with COI primers were prepared with $1.5 \mathrm{mM} \mathrm{MgCl} 2$ $0.2 \mu \mathrm{M}$ of each primer, $0.24 \mathrm{mM}$ dNTPs, $0.04 \mathrm{U} / \mu \mathrm{L}$ Taq DNA Polymerase (PHT Phoneutria $\left.{ }^{\circledR}\right), 1.25 \mu \mathrm{L} 10 \times$ Buffer $(\mathrm{KCL}=500 \mathrm{mM} /$ Tris $\mathrm{HCL}=$ $200 \mathrm{mM}$ ) and $4 \mathrm{ng} / \mu \mathrm{L}$ DNA in $12.5 \mu \mathrm{L}$ final volume. The conditions for amplification were $94{ }^{\circ} \mathrm{C}$ for $2 \mathrm{~min}, 35$ cycles of denaturation at $94{ }^{\circ} \mathrm{C}$ for $30 \mathrm{~s}$, annealing at $54^{\circ} \mathrm{C}$ for $30 \mathrm{~s}$ and extension at $68^{\circ} \mathrm{C}$ for $1 \mathrm{~min}$; with a final extension at $68{ }^{\circ} \mathrm{C}$ for $10 \mathrm{~min}$.

\subsubsection{D-loop region}

The mitochondrial DNA D-loop (control region) was isolated and amplified with the primers A-1-F: 5'TTCCACCTCTAACTCCCAAAG CTAG3' (Lee et al., 1995) and Perc12S1-R: 5'GCGGATACTTGCATG TGTAA3' (Santa Brígida et al., 2007). PCR reactions for amplification of the D-loop were prepared with $1.5 \mathrm{mM} \mathrm{MgCl} 20.2 \mu \mathrm{M}$ of each primer, $0.24 \mathrm{mM}$ dNTPs, $0.04 \mathrm{U} / \mu \mathrm{L}$ Taq DNA Polymerase (PHT Phoneutria ${ }^{\circledR}$ ), $1.25 \mu \mathrm{L} 10 \times$ Buffer $(\mathrm{KCL}=500 \mathrm{mM} /$ Tris $\mathrm{HCL}=200 \mathrm{mM})$ and $4 \mathrm{ng} / \mu \mathrm{L}$ DNA in $12.5 \mu \mathrm{L}$ final volume. The conditions for amplification were $95{ }^{\circ} \mathrm{C}$ for $5 \mathrm{~min}, 35$ cycles of denaturation at $95^{\circ} \mathrm{C}$ for $1 \mathrm{~min}$, annealing at $48.5^{\circ} \mathrm{C}$ for $1 \mathrm{~min}$ and extension at $8{ }^{\circ} \mathrm{C}$ for $1 \mathrm{~min}$; with a final extension at $68^{\circ} \mathrm{C}$ for $5 \mathrm{~min}$.

All PCR amplified products were subjected to enzymatic purification with EXOSAP-IT (UBS Corporation, Cleveland, USA). Sequencing of PCR products was performed using the BigDye kit on an ABI 3730xl automated sequencer (Applied Biosystems, Foster City, USA) by the

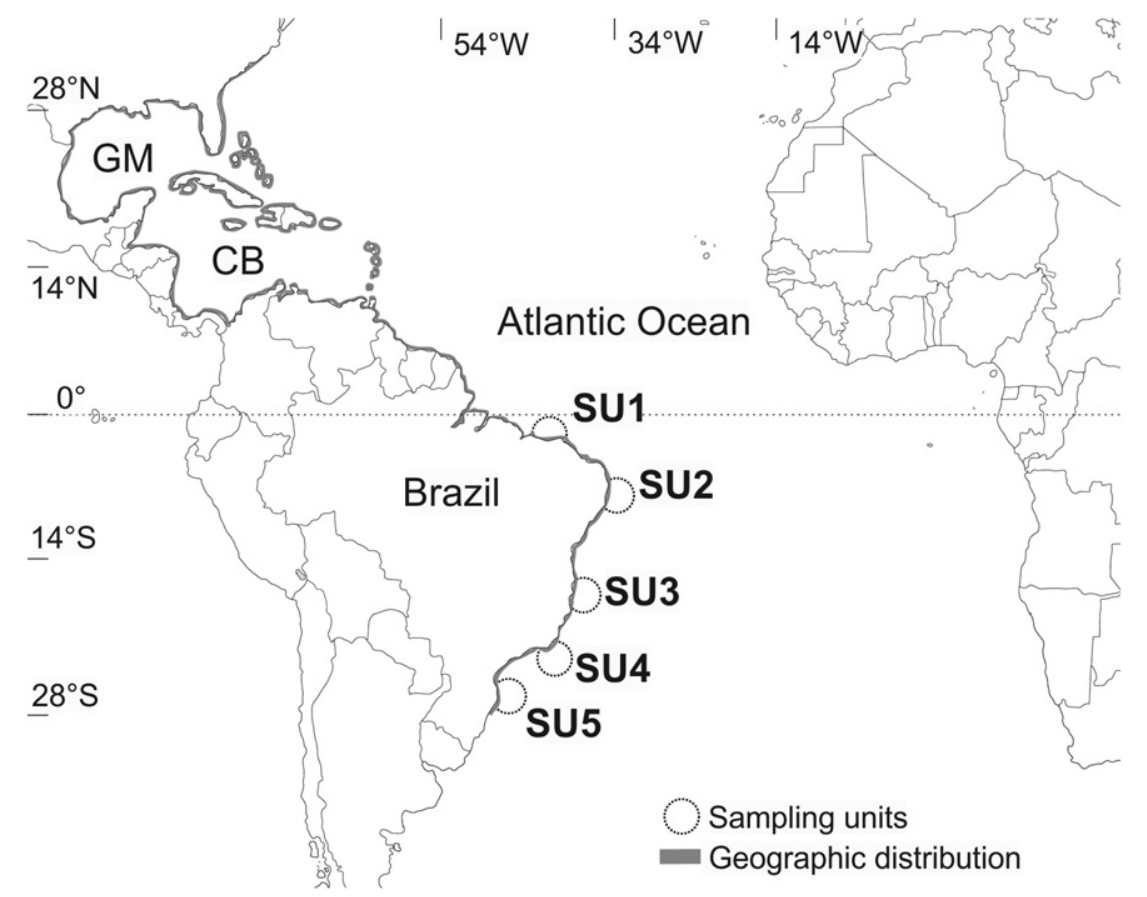

Fig. 1. Location of sampling units (SUs) and geographic distribution of Chaetodipterus faber. GM: Gulf of Mexico; CB: Caribbean; SU: Sampling unit. 
company Macrogen Inc. (Seoul, Korea). All COI and D-loop haplotype sequences produced in this study were deposited in the GenBank database under accession numbers KT367889, КT367966 and КT367967, KT368089, respectively.

\subsection{Data analyses}

Sequences were aligned in the software GENEIOUS 8.0. (Biomatters Limited), and consensus sequences were determined for each individual based on the raw forward and reverse data sequence.

Intraspecific genetic distances of COI dataset were estimated by nucleotide substitution model Kimura-2-parameter, K2P (Kimura, 1980), using the software MEGA 6.0 (Tamura et al., 2013).

The genetic diversity was assessed by haplotype diversity $(h)$, nucleotide diversity $(\pi)$ (Nei, 1987) and the number of polymorphic sites $(S)$, using the software ARLEQUIN 3.5.1.2 (Excoffier et al., 2005).

A minimum-spanning haplotype network was estimated using the TCS software (Clement et al., 2000), which uses the statistical parsimony method of Templeton et al. (1992).

Genetic differentiation between each pair of sampling units was tested using the $\mathrm{F}_{\mathrm{ST}}$ index, through the software ARLEQUIN 3.5.1.2 (Excoffier et al., 2005).

Spatial analysis of molecular variance (SAMOVA) was employed to identify spatial boundaries among SUs, based on K2P molecular distance (Kimura, 1980) as implemented by software SAMOVA 2.0 (Dupanloup et al., 2002). A total of 10,000 simulated annealing processes were used for D-loop datasets to determine optimal allocation of the five SUs into two, three or four clades. Analysis of molecular variance (AMOVA) tested the genetic differentiation at intraregional levels (Excoffier et al., 1992). Pairwise $\mathrm{F}_{\mathrm{ST}}$ and AMOVA analyses were performed based on K2P nucleotide substitution model (Kimura, 1980 ) with 10,100 nonparametric permutations in ARLEQUIN 3.5.1.2 (Excoffier et al., 2005).

In order to check the fit of the historical population dynamics to a model of sudden expansion (Rogers, 1995), a mismatch distribution was conducted (Rogers and Harpending, 1992) along with SSD (Schneider and Excoffier, 1999) and raggedness index (Harpending, 1994) analyses, in ARLEQUIN 3.5.1.2 (Excoffier et al., 2005) based on 10,000 permutations.

Tajima's D-test (Tajima, 1989) and Fu's Fs-test (Fu, 1997) were also estimated to detect any possible deviation from neutrality, with their statistical significance assessed running 1000 permutations in ARLEQUIN 3.5.1.2 (Excoffier et al., 2005).

Demographic history of $C$. faber was analyzed using Bayesian Skyline Plot (BSP) (Drummond et al., 2005). These analyses were run in the BEAST 1.8.2 software (Drummond et al., 2012), based on evolutionary models suggested jModelTest 2.1.8. software (Guindon and Gascuel, 2003; Darriba et al., 2012) and selected according to Akaike and Bayesian information criteria. The analyses were based on strict molecular clock used for the teleost D-loop region, with a substitution rate of $3.6 \%$ per million years (Donaldson and Wilson, 1999; Aboim et al., 2005; Ju et al., 2013). A total of $20^{6}$ generations were run for each dataset to reach effective sample size (ESS) of at least 200. Model comparisons, as well as, burn-in and graphic plots were performed using Tracer 1.6.0 (Rambaut et al., 2014).

\section{Results}

\subsection{Intraspecific genetic distances}

The alignment of the $96 \mathrm{COI}$ sequences from Brazil (generated $=78$, BOLD $=18$ ), with eight sequences (all from BOLD) available from the Gulf of Mexico and the Caribbean, resulted in a matrix with 104 sequences of 620 base pairs (bp).

The $104 \mathrm{COI}$ sequences analyzed, revealed only five haplotypes with four polymorphic sites $(0.64 \%)$. Haplotype $\mathrm{H} 5_{\mathrm{CoI}}$ was the most common, shared among all Brazilian sampling units and beyond, to the Gulf of Mexico and the Caribbean (Table 2). Haplotype $\mathrm{H} 1_{\mathrm{CoI}}$ was not observed among the Brazilian samples, but in four Caribbean samples only.

The average nucleotide composition of the COI sequences was $23.5 \%$ adenine, $26.0 \%$ thymine, $32.1 \%$ cytosine and $18.4 \%$ guanine, with four transitions and no transversions. The K2P intraspecific genetic divergence found, among all COI sequences, was between $0.001 \%$ and $0.32 \%$ with an average divergence between haplotypes of $0.25 \%$.

The alignment of 123 mitochondrial DNA D-loop region sequences resulted in a matrix of $817 \mathrm{bp}$. Sequence analyses detected 76 polymorphic sites and 69 haplotypes, where $\mathrm{H} 25$ was the most frequent. The average nucleotide composition of the D-loop region was $30.0 \%$ adenine, $36.0 \%$ thymine, $13.7 \%$ cytosine and $20.3 \%$ guanine, with 66 transitions and four transversions.

Haplotype (h) and nucleotide $(\pi)$ diversities obtained in the analysis of the D-loop region sequences are presented in Table 3 . The nucleotide diversity within each SU ranged from 0.0013 to 0.0097 . The pattern of high haplotype diversity and low nucleotide diversity was found for all SUs, where the southern ones (SU4 and SU5) presented the lowest diversity values.

\subsection{Population structure}

The network analysis presented a Tropical clade with 52 D-loop haplotypes, while the Subtropical clade had 18 D-loop haplotypes. The former was characterized by the predominance of unique haplotypes and consequently a low sharing (9.6\%) among SUs, while the latter had a high representativeness of haplotype 25 (H25 = 53.8\%) and associated low divergence between haplotypes. A single haplotype shared between Tropical and Subtropical clades was the most representative in the Subtropical region (H25) and was shared only with the southernmost SUs of the Tropical region (SU2 and SU3).

The haplotype network suggested the existence of two groups formed by SU1 + SU2 + SU3, named the Tropical clade and SU4 + SU5, named the Subtropical clade, which showed at least six mutations between groups and only one shared haplotype (Fig. 2).

The pairwise comparisons corroborated the hypothesis of two clades observed in the haplotype network. Values of $\mathrm{F}_{\mathrm{ST}}$ (Table 4) indicate no significant differences between SUs in the Tropical clade and neither in the Subtropical clade. Considering the SUs of different clades, the difference was always significantly high, with $\mathrm{F}_{\mathrm{ST}}$ values ranging from 0.63 to 0.74 .

Results from SAMOVA support regional genetic subdivision among clusters of SUs (Table 5$)$. In spite of the low significance $(p=0.08)$ of the source of variance, SAMOVA results indicated maximal variance among groups (63.59\%) at $\mathrm{k}=2$, with one group comprised of all three Tropical SUs (SU1, SU2 and SU3) and another group comprised of both Subtropical SUs (SU4 and SU5).

Intraregional AMOVA approach considering Tropical and Subtropical datasets attributed a much higher percentage of genetic variance to within rather than between SUs at both regions separately (Table 6), supporting the unit of each clade as observed in the haplotype network and pairwise $\mathrm{F}_{\mathrm{ST}}$.

Table 2

Frequency of the five COI haplotypes of Chaetodipterus faber found among Gulf of Mexico, Caribbean Sea and Brazil.

\begin{tabular}{lllll}
\hline Haplotypes & Gulf & Caribbean & Brazil & Total \\
\hline H1 ${ }_{\text {COI }}$ & & 04 & & 04 \\
H2 coI & & & 01 & 01 \\
H3 coI & & 01 & 01 \\
H4 coI & 01 & 03 & 01 & 01 \\
H5 coI & 01 & 07 & 93 & 97 \\
Total & 01 & 96 & 104 \\
\hline
\end{tabular}


Table 3

Genetic diversity of Chaetodipterus faber from five sampling units (SUs) distributed along the Brazilian coast, using mitochondrial D-loop sequences.

\begin{tabular}{llllll}
\hline Clades/SUs & $\mathrm{N}$ & $\mathrm{H}$ & $\mathrm{S}$ & $\mathrm{h} \pm \mathrm{SE}$ & $\pi \pm \mathrm{SE}$ \\
\hline Tropical clade & 71 & 52 & 70 & $0.9883 \pm 0.004$ & $0.0090 \pm 0.004$ \\
SU1 & 29 & 25 & 50 & $0.9901 \pm 0.011$ & $0.0097 \pm 0.005$ \\
SU2 & 12 & 9 & 27 & $0.9545 \pm 0.046$ & $0.0083 \pm 0.004$ \\
SU3 & 30 & 23 & 43 & $0.9816 \pm 0.013$ & $0.0076 \pm 0.004$ \\
Subtropical clade & 52 & 18 & 18 & $0.7564 \pm 0.055$ & $0.0015 \pm 0.001$ \\
SU4 & 24 & 11 & 13 & $0.8007 \pm 0.071$ & $0.0019 \pm 0.001$ \\
SU5 & 28 & 11 & 10 & $0.7328 \pm 0.082$ & $0.0013 \pm 0.0009$ \\
All samples & 123 & 69 & 76 & $0.9403 \pm 0.016$ & $0.0102 \pm 0.0053$ \\
\hline
\end{tabular}

$\mathrm{N}$ : number of sequences per site; $\mathrm{H}$ : number of haplotypes; $\mathrm{S}$ : number of polymorphic sites; h: haplotype diversity; $\pi$ : nucleotide diversity; SE: standard error.

\subsection{Demographic history}

Pairwise mismatch distribution and results of neutrality tests performed for both clades are given in Fig. 3. The significantly negative values of Tajima's D-test and Fu's Fs-test (Table 7) indicate a rarer nucleotide site variant than expected under a neutral evolution model.

Although the Tropical clade showed a bimodal pattern, pairwise mismatch distribution for both clades did not reject Rogers' (1995) model of sudden expansion (Fig. 3), as evidenced by non-significant p-values of SSD and Rg tests (Table 7).

The Bayesian Skyline Plot (BSP) indicated the historical occurrence of increase in the effective size of both clades. BSP analysis performed based on HKY + I model (as suggested by jModelTest) for C. faber Dloop data indicate a recent event of population expansion of the Tropical clade starting at about $50 \mathrm{kyr}$ ago, reaching a stable effective population size around $10 \mathrm{kyr}$ ago (Fig. 4). Differently, the BSP suggested a less

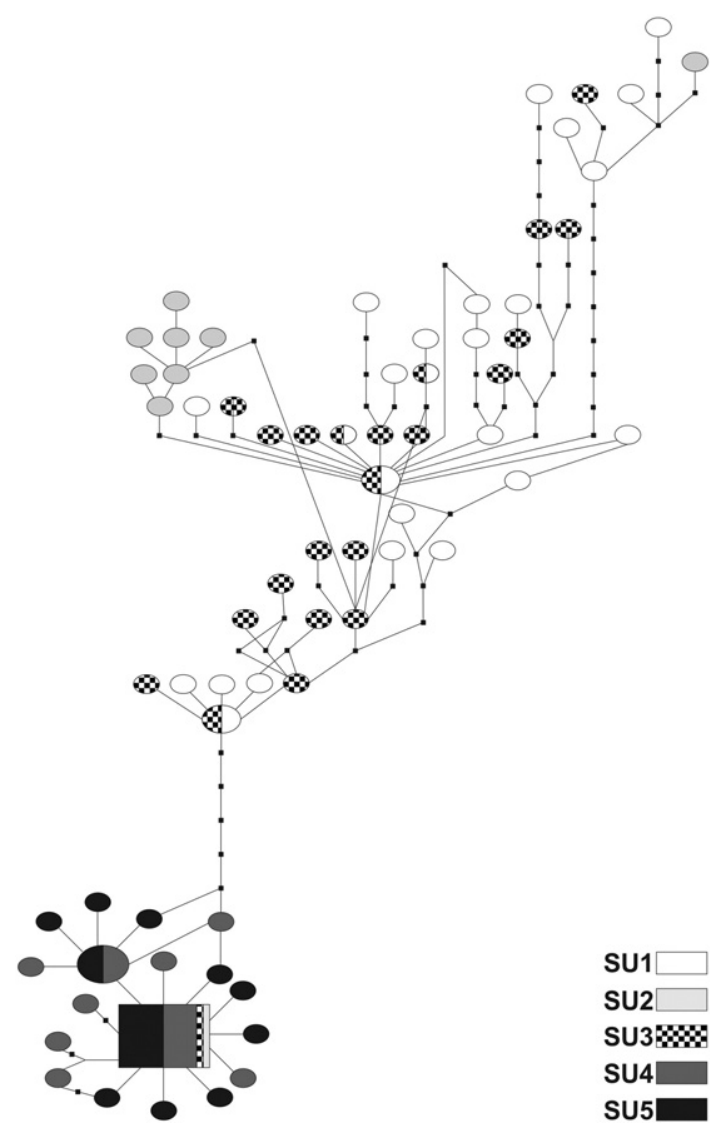

Fig. 2. Minimum-spanning haplotype network of the mitochondrial DNA D-loop region of 123 individuals of Chaetodipterus faber from five sampling units (SUs) distributed along the Brazilian coast.
Table 4

Matrix of pairwise $\mathrm{F}_{\mathrm{ST}}$ values for Chaetodipterus faber mitochondrial D-loop haplotypes from five sampling units (SUs) distributed along the Brazilian coast. SUs in ascending order from North to South.

\begin{tabular}{lllll}
\hline Sample units & SU1 & SU2 & SU3 & SU4 \\
\hline SU2 & -0.0086 & & & \\
SU3 & 0.0142 & -0.0090 & & \\
SU4 & $0.6369^{*}$ & $0.7023^{*}$ & $0.6377^{*}$ & \\
SU5 & $0.6653^{*}$ & $0.7448^{*}$ & $0.6671^{*}$ & -0.0081 \\
\hline$* \mathrm{p}<0.001$ & & & &
\end{tabular}

intense demographic increase occurring in Subtropical clade, between approximately 10 and 7.5 kyr ago (Fig. 5).

\section{Discussion}

The analysis of $C$. faber COI datasets leads to a pairwise K2P genetic divergence from 0.001 to $0.32 \%$. These results are in agreement with intraspecific divergence values observed for marine fish from Western Atlantic (Ribeiro et al., 2012; Valdez-Moreno et al., 2010; Weigt et al., 2012) and in other parts of the world (Hubert et al., 2012; Rock et al., 2008; Ward et al., 2005; Zhang, 2011). The most conserved nature of COI did not provide an evidence of population structure, but confirmed that the dataset belongs to a single species distributed from the Gulf of Mexico to south Brazil. Erroneous or imprecise fish identification is a major problem for fisheries management (Lleonart et al., 2006). Therefore, $\mathrm{COI}$ sequences deposited in the GenBank database (accession numbers KT367889 and KT367966) will certainly contribute to minimize problems related to species identification, since these sequences became part of the universal identification system proposed by Hebert et al. (2003).

Regarding the mtDNA D-loop, results showed moderate to high haplotype diversity $(h)$ and low nucleotide diversity $(\pi)$ when compared with other marine fishes (Aboim et al., 2005; Damasceno et al., 2015; Ju et al., 2013; Planes et al., 2001; Stepien et al., 2001; Santos et al., 2006). Furthermore, a significant genetic divergence between Tropical and Subtropical groups of $C$. faber in SW Atlantic was identified, suggesting a restriction to gene flow. Population structuring of marine fish populations between Tropical and Subtropical regions along the Brazilian coast has been evidenced in recent studies (Accioly et al., 2012; Affonso and Galetti, 2007; Galetti et al., 2006; Molina et al., 2006; Santos et al., 2006).

The causes of population structuring in marine fishes are yet to be well understood. Furthermore, ocean circulation patterns, temperature regimes, coastal topography, environmental requirements and life history of species are among the main explaining factors (Bay et al., 2004; Santos et al., 2006). In the case of Tropical and Subtropical regions

Table 5

Spatial analysis of molecular variance (SAMOVA) for Chaetodipterus faber D-loop haplotypes from five sampling units (SUs) allocated into two, three or four groups.

\begin{tabular}{lllll}
\hline Groups/source of variation & Variance & Variation (\%) & $\Phi$ & p-value \\
\hline $\mathrm{k}=$ 2: (1) SU1, SU2 and SU3 (2) & & & & \\
$\quad$ SU4 and SU5 & & & & \\
$\quad$ Among groups & 3.620 & 63.59 & 0.636 & $=0.087$ \\
$\quad$ Among populations within groups & 0.017 & 0.30 & 0.008 & $=0.346$ \\
$\quad$ Within populations & 2.056 & 36.11 & 0.639 & $<0.001$ \\
$\mathrm{k}=$ 3: (1) SU1 and SU3 (2) SU2 (3) & & & & \\
SU4 and SU5 & & & & \\
Among groups & 3.037 & 59.43 & 0.594 & $=0.052$ \\
$\quad$ Among populations within groups & 0.017 & 0.34 & 0.008 & $=0.171$ \\
$\quad$ Within populations & 2.056 & 40.23 & 0.598 & $<0.001$ \\
$\mathrm{k}=$ 4: (1) SU1 (2) SU2 (3) SU3 (4) & & & & \\
$\quad$ SU4 and SU5 & & & & \\
$\quad \begin{array}{l}\text { Among groups } \\
\text { Among populations within groups }\end{array}$ & -0.062 & -1.34 & -0.031 & $=0.540$ \\
$\quad$ Within populations & 2.056 & 44.55 & 0.555 & $<0.001$ \\
\hline
\end{tabular}


Table 6

Intraregional analysis of molecular variance (AMOVA) for Chaetodipterus faber D-loop haplotypes from five sampling units (SUs) allocated in two clades. In "Tropical clade" SU1, SU2 and SU3; In "Subtropical clade" SU4 and SU5.

\begin{tabular}{lllll}
\hline Clade/source of variation & Variance & Variation (\%) & $\Phi$ & p-value \\
\hline Tropical clade & & & & \\
$\quad$ Among populations & 0.014 & 0.43 & & \\
$\quad$ Within populations & 3.144 & 99.57 & 0.004 & $=0.316$ \\
$\begin{array}{c}\text { Subtropical clade } \\
\text { Among populations }\end{array}$ & -0.005 & -0.82 & & \\
$\quad$ Within populations & 0.576 & 100.82 & -0.008 & $=0.528$ \\
\hline
\end{tabular}

in the SW Atlantic, the differences in seawater temperature related to ocean circulation pattern and the presence of a well-known upwelling events in Cabo Frio $\left(23^{\circ} \mathrm{S}\right)$ have been regarded as the key factor accounting for the barrier to gene flow of some fish species (Galetti et al., 2006; Santos et al., 2006). This phenomenon promotes drastic changes in environmental conditions, which would be responsible for population genetic differences as a result of adaptations to the local thermal regime.

A more detailed analysis on Tropical haplotype network evidenced a lack of shared haplotypes between SU2 and other Tropical SUs. These observations highlight the need of studies along the NE Brazilian coast, mainly using SNPs or microsatellite markers to better understand such pattern. The hypothesis of larval retention appears to be one of the main explanations to be evaluated, especially in a species like $C$. faber, which gather in spawning aggregations and depend on estuarine environments for larval and juvenile development (Barros et al., 2013; Bittencourt, 1990; Ditty et al., 1994; Hayse, 1990; Damasceno et al., 2015). Larval retention by aggregated spawning species may be selectively advantageous to ensure the access of larvae and juveniles to necessary resources (Portnoy et al., 2013). Moreover, resident breeding groups may potentialize larval retention resulting in reduced gene flow (Damasceno et al., 2015).

a)
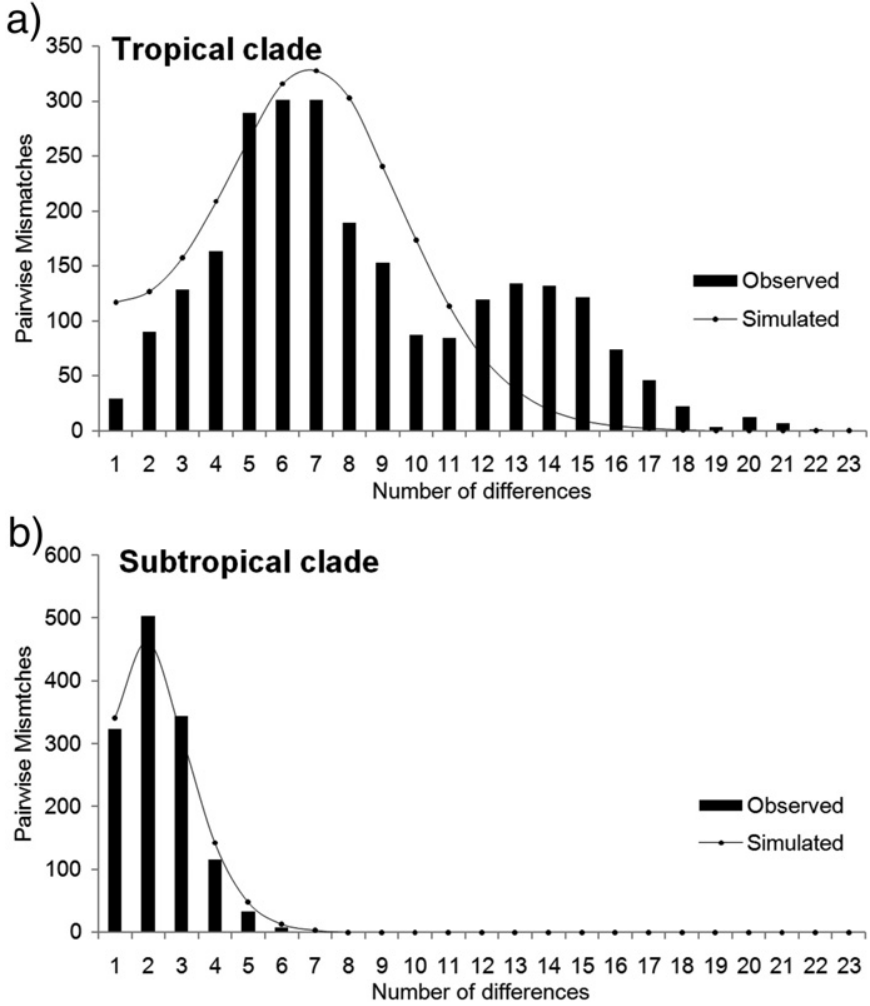

Fig. 3. Pairwise mismatch distributions based on mitochondrial D-loop region sequences of Chaetodipterus faber clades from SW Atlantic.
Table 7

Neutrality tests and demographic expansion parameters with respective significance, for each clade of Chaetodipterus faber from SW Atlantic, based on mitochondrial D-loop data. SSD: sum of squared deviations; Rg: Harpending's Raggednes index.

\begin{tabular}{lll}
\hline & Tropical & Subtropical \\
\hline Tajima's D & -1.7537 & -2.0883 \\
$\mathrm{p}$ & 0.010 & 0.002 \\
Fu's Fs & -24.9401 & -16.5015 \\
$\mathrm{p}$ & $>0.001$ & $>0.001$ \\
SSD & 0.0139 & 0.0022 \\
$\mathrm{p}$ & 0.120 & 0.481 \\
Rg & 0.0075 & 0.0668 \\
$\mathrm{p}$ & 0.915 & 0.292 \\
\hline
\end{tabular}

A single D-loop haplotype (H25) was shared between Tropical and Subtropical clades of $C$. faber. This haplotype, while uncommon in the Tropical clade, is present in more than half $(53.8 \%)$ of individuals from the Subtropical clade. The central importance of H25 to the Subtropical clade star-shaped haplotype network, suggests it as an ancestral haplototype of this region.

These results indicate an allopatric divergence with peripheral isolation. Such effective restriction to gene flow, essential for allopatric divergence (Rocha and Bowen, 2008) may be responsible for the single haplotype (H25) shared between clades. All other haplotypes typical of the Southern limit of the species distribution (Subtropical clade) were not observed in any SU of the Tropical clade. The allopatric divergence through peripheral isolation associated with the genetic drift would also be responsible for the loss of haplotype and nucleotide diversities in the Subtropical clade (Santos et al., 2006), which can explain the significantly lower values of diversity registered in both SUs further south (see Table 3 ).

Tajima's D-tests and Fu's Fs-test on overall sequences of both clades revealed negative and significant values, which provided evidence for deviation from neutrality (Tajima, 1989; Fu, 1997). Both clades have undergone population expansion as indicated by the lack of significant values of SSD and Rg indexes (Rogers, 1995). These outcomes are in accordance with the pattern of high haplotype diversity and low nucleotide diversity observed in all D-loop dataset, which is usually attributed to recent population expansion, after a period of low effective population caused by bottleneck or founder events (Grant and Bowen, 1998). Pairwise mismatch distributions of the Tropical clade are more consistent with a weak and/or old bottleneck, followed by a population expansion, which also lacks satellite haplotypes. In contrast, the presence of these haplotypes distinguished by one or two mutations in the Subtropical dataset suggests that this clade might have undergone a more recent and/or strong bottleneck or founder event (see Fauvelot et al., 2003).

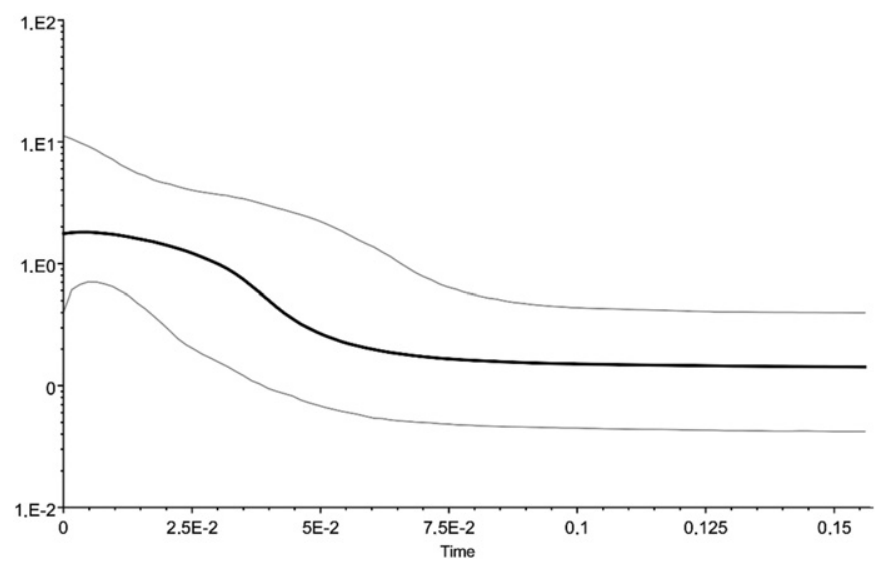

Fig. 4. Bayesian skyline plot of effective population size through time for Tropical clade of Chaetodipterus faber in SW Atlantic, using mitochondrial D-loop sequences. Center line: median estimation; upper and lower lines: limits of 95\% confidence interval. 


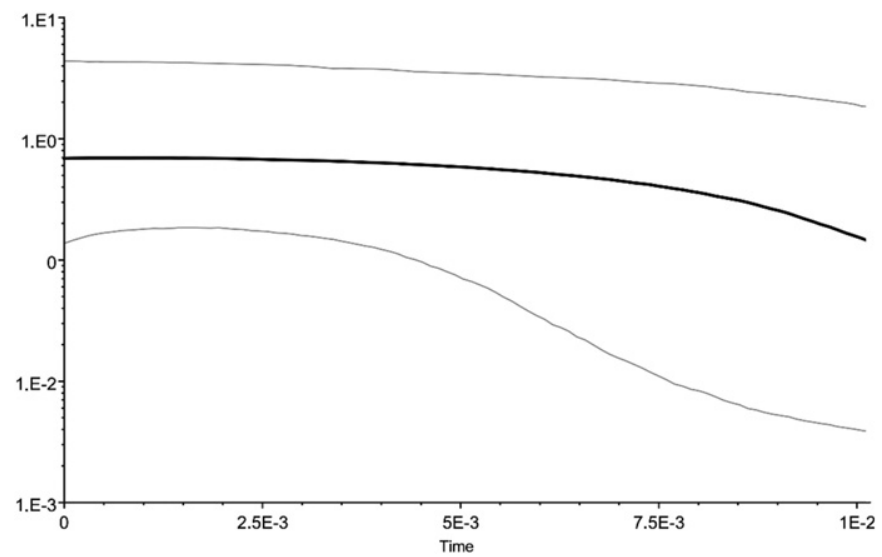

Fig. 5. Bayesian skyline plot of effective population size through time for Subtropical clade of Chaetodipterus faber in SW Atlantic, using mitochondrial D-loop sequences. Center line: median estimation; upper and lower lines: limits of 95\% confidence interval.

The BSP supported the hypothesis of time divergent events of population expansion between the observed clades for southwestern C. faber. Also, it clearly showed the expansion of the Tropical clade starting approximately $50 \mathrm{kyr}$ ago reaching demographic stability at the end of last glacial maximum ( $10 \mathrm{kyr}$ ago $)$. This period was characterized by secondary extreme and short-lived events (known as Heinrich events), where temperature drop-offs and sea level fluctuations, reached $130 \mathrm{~m}$ lower than today (Adams et al., 1999; Chappell and Shackleton, 1986; Reis et al., 2013; Rossetti et al., 2015). Such severe climatic and sea level fluctuations during the late Pleistocene (Adams et al., 1999) have been suggested as strong influence in shaping patterns of genetic variability and the geographic distribution of marine fauna (Almada et al., 2001; Domingues et al., 2006, 2007a, 2007b; Santos et al., 2006; Stefanni et al., 2006). Genetic signatures of population expansion produced by environmental changes of the late Pleistocene have been worldwide documented for marine fishes such as Ocyurus chrysurus (25 kyr ago; Silva et al., 2015); Engraulis mordax (61kyr ago; DíazViloria et al., 2012), Sicyopterus japonicus (135 to 25 kyr ago; Ju et al., 2013) and Cephalopholis fulva (148 to 131 kyr ago; Souza et al., 2015).

Concerning the Subtropical clade, several demographic analyses indicate that the population has experienced a size increase. Moreover, results from demographic analyses suggest that the Subtropical clade has a population expansion starting around $10 \mathrm{kyr}$ ago, following Tropical clade demographic stability, in a period subsequent to last glacial maximum (Pleistocene-Holocene transition). In fact, the period of Subtropical clade population expansion observed in BSP results, corresponds to the beginning of the interglacial period when global climatic conditions were characterized by deglaciation, sea level rise, ocean warming and current changes which lasted from 11,650 to 7000 years ago (Smith et al., 2011). According to Damuth and Fairbridge (1970), during glaciations, the Subtropical Convergence Zone was located near Espírito Santo coast $\left(20^{\circ} \mathrm{S}\right)$, however, during interglacial periods, the cold water zone moved southwards and probably allowed the adaptive radiation in this direction, as observed for M. ancylodon (Santos et al., 2006) and now for $C$. faber.

\section{Conclusions}

The present study is the most comprehensive investigation of the SW Atlantic populations of $C$. faber undertaken to date. Results indicate that $C$. faber is not panmictic, revealing genetic structuring at the mitochondrial DNA level between Tropical and Subtropical regions in Brazil. Population genetic comparisons exposing these distinct clades also suggest a pattern of allopatric differentiation by peripheral isolation generating lower haplotype diversity in the Subtropical clade. Several demographic analyses, as well as, the pattern of high haplotype diversity and low nucleotide diversity (in both clades), highlight a population expansion after a period of low effective population size caused by bottlenecks due to founder events. Population size reconstructions analysis showed a Subtropical population expansion immediately after Tropical clade attained its demographic stability. Demographic expansion of both clades appears to be related to historical events of oceanographic changes, during the Pleistocene-Holocene transition, as observed for several marine species. Moreover, the population size increase observed in the Subtropical clade may reflect a C. faber colonization of southernmost region, consequence of a relocation to south of the Subtropical Convergence Zone after the Last Glacial Maximum.

\section{Acknowledgements}

The authors are grateful to Conselho Nacional de Desenvolvimento Científico e Tecnológico (CNPq: 350311/2012-9), Fundação de Amparo à Pesquisa e Inovação do Espírito Santo (FAPES: 54515130/2011), Programa de Pós-graduação em Biodiversidade Tropical (CEUNES/ UFES), Programa de Pós-graduação em Ciências Biológicas-Zoologia (IBB/UNESP), and Instituto Chico Mendes de Conservação da Natureza (SISBIO: 38970-1). LFM and AAB are recipients of Postdoctoral scholarship from CAPES/PNPD. The authors wish to express particular thanks to Orjana Lara Risch, Thiago “Abú" de Souza, Leonardo Bueno and Felippe Daros for invaluable contribution in the field. [SS]

\section{References}

Aboim, M.A., Menezes, G.M., Schlitt, T., Rogers, A.D., 2005. Genetic structure and history of populations of the deep-sea fish Helicolenus dactylopterus (Delaroche, 1809) inferred from mtDNA sequence analysis. Mol. Ecol. 14, 1343-1354.

Accioly, I.V., Bertollo, L.A.C., Costa, G.W.W.F., Jacobina, U.P., Molina, W.F, 2012. Chromosomal population structuring in carangids (Perciformes) between the north-eastern and south-eastern coasts of Brazil. Afr. J. Mar. Sci. 34 (3), 383-389.

Adams, J., Maslin, M., Thomas, E., 1999. Sudden climate transitions during the Quaternary. Prog. Phys. Geogr. 23 (1), 1-36.

Affonso, P.R.A.M., Galetti Jr., P.M., 2007. Genetic diversity of three ornamental reef fishes (Families Pomacanthidae and Chaetodontidae) from the Brazilian coast. Braz. J. Biol. 67 (4), 925-933.

Aljanabi, S.M., Martinez, I., 1997. Universal and rapid salt-extraction of high quality genomic DNA for PCR-based techniques. Nucleic Acids Res. 25, 4692-4693.

Almada, V.C., Oliveira, R.F., Gonçalves, E.J., Almeida, A.J., Santos, R.S., Wirtz, P., 2001. Patterns of diversity of the northeastern Atlantic blennid fish fauna (Pisces: Blenniidae). Glob. Ecol. Biogeogr. 10, 411-422.

Barros, B., Sakai, Y., Abrunhosa, F.A., Vallinoto, M., 2013. Trophic adaptability of late juvenile Atlantic spadefish Chaetodipterus faber (Teleostei: Ephippidae) related to habitat preferences in an estuary in northeastern Brazil. Hydrobiologia 717 (1), 161-167.

Bay, L.K., Choat, J.H., van Herwerden, L., Robertson, D.R., 2004. High genetic diversities and complex genetic structure in an Indo-Pacific tropical reef fish (Chlorurus sordidus): evidence of an unstable evolutionary past? Mar. Biol. 144 (4), 757-767.

Bittencourt, M.L., 1990. Preliminary investigations about trophic relations of Atlanticspadefish Chaetodipterus faber (Broussonet, 1782), (Pisces, Ephippidae) in the Guaraquecaba Bay, estuarine complex of Paranagua (Parana State, Brazil). Braz Arch. Biol. Technol. 33, 195-203.

Böhlke, J.E., Chaplin, C.C.G., 1993. Fishes of the Bahamas and Adjacent Tropical Waters second ed. University of Texas Press, Austin.

Bowen, B.W., Shanker, K., Yasuda, N., Celia, M., Malay, M.C.M.D., von der Heyden, S., Paulay, G., Rocha, L.A., Selkoe, K.A., Barber, P.H., Williams, S.T., Lessios, H.A. Crandall, E.D., Bernardi, G., Meyer, C.P., Carpenter, K.E., Toonen, R.J., 2014 Phylogeography unplugged: comparative surveys in the genomic era. Bull. Mar. Sci. 90 (1), 13-46

Burgess, W.E., 2002. Ephippidae. In: Carpenter, K.E. (Ed.), FAO (Food and Agriculture Organization) Species Identification Guide for Fishery Purposes: The Living Marine Resources of the Western Central AtlanticBony fishes part 2 (Opistognathidae to Molidae), sea turtles and marine mammals vol. 3. FAO, Rome, pp. 1799-1800.

Chappell, J., Shackleton, N.J., 1986. Oxygen isotopes and sea level. Nature 324, 137-140.

Clarke, C.R., Karl, S.A., Horn, R.L., Bernard, A.M., Lea, J.S., Hazin, F.H., Prodohl, P.A., Shivji, M.S., 2015. Global mitochondrial DNA phylogeography and population structure of the silky shark, Carcharhinus falciformis. Mar. Biol. 162 (5), 945-955.

Clement, M., Posada, D., Crandall, K.A., 2000. TCS: a computer program to estimate gene genealogies. Mol. Ecol. 9, 1657-1659.

Damasceno, J.S., Siccha-Ramirez, R., Morales, M.J., Oliveira, C., Torres, R.A., Costa, E.N., Silva-Oliveira, C., Vallinotto, M., Machado, L.F., Tosta, V.C., Farro, A.P.C., Hostim-Silva, M., 2015. Mitochondrial DNA evidences reflect an incipient population structure in Atlantic goliath grouper (Epinephelus itajara, Epinephelidae) in Brazil. Sci. Mar. 79 (4), 419-429.

Damuth, F.M., Fairbridge, R.W., 1970. Equatorial Atlantic deep-sea arkosic sands and iceage aridity in tropical South America. Geol. Soc. Am. Bull. 81, 189-206. 
Darriba, D., Taboada, G.L., Doallo, R., Posada, D., 2012. jModelTest 2: more models, new heuristics and parallel computing. Nat. Methods 9 (8), 772.

Díaz-Viloria, N., Sánchez-Velasco, L., Pérez-Enríquez, R., 2012. Recent population expansion in the evolutionary history of the Californian anchovy Engraulis mordax. Hidrobiológica 22 (3), 258-266.

Ditty, J.G., Shaw, R.F., Cope, J.S., 1994. A re-description of Atlantic spadefish larvae, Chaetodipterus faber (family: Ephippidae), and their distribution, abundance, and seasonal occurrence in the northern Gulf of Mexico. Fish B-NOAA 92, 262-274.

Domingues, V.S., Almada, V.C., Santos, R.S., Brito, A., Bernardi, G., 2007a. Phylogeography and evolution of the triplefin Tripterygion delaisi (Pisces, Blennioidei). Mar. Biol. $150,509-519$

Domingues, V.S., Santos, R.S., Brito, A., Alexandrou, M., Almada, V.C., 2007b. Mitochondrial and nuclear markers reveal isolation by distance and effects of Pleistocene glaciations in the northeastern Atlantic and Mediterranean populations of the white seabream (Diplodus sargus, L.). J. Exp. Mar. Biol. Ecol. 346, 102-113.

Domingues, V.S., Santos, R.S., Brito, A., Almada, V.C., 2006. Historical population dynamics and demography of the eastern Atlantic pomacentrid Chromis limbata (Valenciennes, 1833). Mol. Phylogenet. Evol. 40, 139-147.

Donaldson, K.A., Wilson, R.R., 1999. Amphi-Panamic geminates of snook (Percoidei: Centropomidae) provide a calibration of the divergence rate in the mitochondrial DNA control region of fishes. Mol. Phylogenet. Evol. 13, 208-213.

Drummond, A.J., Rambaut, A., Shapiro, B., Pybus, O.G., 2005. Bayesian coalescent inference of past population dynamics from molecular sequences. Mol. Biol. Evol. 22, $1185-1192$.

Drummond, A.J., Suchard, M.A., Xie, D., Rambaut, A., 2012. Bayesian phylogenetics with BEAUti and the BEAST 1.7. Mol. Biol. Evol. 29, 1969-1973.

Dupanloup, I., Schneider, S., Excoffier, L., 2002. A simulated annealing approach to define the genetic structure of populations. Mol. Ecol. 11, 2571-2581.

Excoffier, L., Laval, L.G., Schneider, S., 2005. Arlequin ver. 3.5: an integrated software package for population genetics data analysis. Evol. Biol. Online 1, 47-50.

Excoffier, L., Smouse, P., Quattro, J.M., 1992. Analysis of molecular variance inferred from metric distances among DNA haplotypes: application to human mitochondrial DNA restriction data. Genetics 131, 479-491.

Fauvelot, C., Bernardi, G., Planes, S., 2003. Reductions in the mitochondrial DNA diversity of coral reef fish provide evidence of population bottlenecks resulting from Holocene sea-level change. Evolution 57 (7), 1571-1583.

Fu, Y.X., 1997. Statistical tests of neutrality of mutations against population growth, hitchhiking and background selection. Genetics 147, 915-925.

Galetti Jr., P.M., Molina, W.F., Affonso, P.R.A., Aguilar, C.T., 2006. Assessing genetic diversity of Brazilian reef fishes by chromosomal and DNA markers. Genetica 126, 161-177.

Grant, W.S., Bowen, B.W., 1998. Shallow population histories in deep evolutionary lineages of marine fishes: insights from sardines and anchovies and lessons for conservation. J. Hered. 89, 415-426.

Guindon, S., Gascuel, O., 2003. A simple, fast and accurate method to estimate large phylogenies by maximum-likelihood. Syst. Biol. 52, 696-704.

Harpending, H.C., 1994. Signature of ancient population growth in a low-resolution mitochondrial DNA mismatch distribution. Hum. Biol. 66, 591-600.

Hayse, J.W., 1990. Feeding habits, age, growth, and reproduction of Atlantic spadefish Chaetodipterus faber (Pisces: Ephippidae) in South Carolina. Fish B NOAA 88, 67-83.

Hebert, P.D.N., Ratnasingham, S., de Waard, J.R., 2003. Barcoding animal life: cytochrome c oxidase subunit 1 divergences among closely related species. Proc. R. Soc. Lond. B Biol. Sci. 270, S96-S99 (Suppl.)

Hedrick, P., 2009. Population genetics and ecology. In: Levin, S.A., Carpenter, S.R., Godfray, H.C.J., Kinzig, A.P., Loreau, M., Losos, J.B., Wilcove, D.S. (Eds.), The Princeton Guide to Ecology. Princeton University Press, New York.

Hostim-Silva, M., Andrade, A.B., Machado, L.F., Gerhardinger, L.C., Daros, F.A., Barreiros, J.P., Godoy, E., 2006. Peixes de Costão Rochoso de Santa Catarina. I. Arvoredo. Editora UNIVALI, Itajaí, Brasil.

Hubert, N., Meyer, C.P., Bruggemann, H.J., Guerin, F., Komeno, R.J., Espiau, B., Causse, R., Willians, J.T., Planes, S., 2012. Cryptic diversity in Indo-Pacific coral-reef fishes revealed by DNA-barcoding provides new support to the centre-of-overlap hypothesis. PLoS ONE 7 (3), e28987.

IBAMA, 2003. Instituto Brasileiro do Meio Ambiente e dos Recursos Naturais Renováveis-Estatística da pesca 2001 Brasil: grandes regiões e unidades da federação/Brasília: Ibama, 2003. 97 pp. http://www.ibama.gov.br/documentosrecursos-pesqueiros/estatistica-pesqueira (Accessed 25 June 2015).

IBAMA, 2004a. Instituto Brasileiro do Meio Ambiente e dos Recursos Naturais Renováveis-Estatística da pesca 2002 Brasil: grandes regiões e unidades da federação/Brasília: Ibama, 2004. 97 pp. http://www.ibama.gov.br/documentosrecursos-pesqueiros/estatistica-pesqueira (Accessed 25 June 2015).

IBAMA, 2004b. Instituto Brasileiro do Meio Ambiente e dos Recursos Naturais Renováveis-Estatística da pesca 2003 Brasil: grandes regiões e unidades da federação/Brasília: Ibama, 2004. 98 pp. http://www.ibama.gov.br/documentosrecursos-pesqueiros/estatistica-pesqueira (Accessed 25 June 2015).

IBAMA, 2005. Instituto Brasileiro do Meio Ambiente e dos Recursos Naturais Renováveis-Estatística da pesca 2004 Brasil: grandes regiões e unidades da federação/Brasília: Ibama, 2005. 98 pp. http://www.ibama.gov.br/documentosrecursos-pesqueiros/estatistica-pesqueira (Accessed 25 June 2015).

IBAMA, 2007a. Instituto Brasileiro do Meio Ambiente e dos Recursos Naturais Renováveis-Estatística da pesca 2005 Brasil: grandes regiões e unidades da federação/Brasília: Ibama, 2007. 108 pp. http://www.ibama.gov.br/documentosrecursos-pesqueiros/estatistica-pesqueira (Accessed 25 June 2015).

IBAMA, 2007b. Instituto Brasileiro do Meio Ambiente e dos Recursos Naturais Renováveis-Estatística da pesca 2007 Brasil: grandes regiôes e unidades da federação/Brasília: Ibama, 2007. 113 pp. http://www.ibama.gov.br/documentosrecursos-pesqueiros/estatistica-pesqueira (Accessed 25 June 2015).
IBAMA, 2008. Instituto Brasileiro do Meio Ambiente e dos Recursos Naturais Renováveis-Estatística da pesca 2006 Brasil: grandes regiões e unidades da federação/Brasília: Ibama, 2008. 174 pp. http://www.ibama.gov.br/documentosrecursos-pesqueiros/estatistica-pesqueira (Accessed 25 June 2015).

Ju, Y.M., Hsu, C.H., Fang, L.S., Lin, H.D., Wu, J.H., Han, C.C., Chen, I.S., Chiang, T.Y., 2013. Population structure and demographic history of Sicyopterus japonicus (Perciformes; Gobiidae) in Taiwan inferred from mitochondrial control region sequences. Genet. Mol. Res. 12 (3), 4046-4059.

Kimura, M., 1980. A simple method for estimating evolutionary rate of base substitution through comparative studies of nucleotide sequences. J. Mol. Evol. 16, 111-120.

Lee, W.J., Conroy, J., Howell, W.H., Kocher, T.D., 1995. Structure and evolution of teleost mitochondrial control regions. J. Mol. Evol. 41, 54-66.

Lleonart, J., Taconet, M., Lamboeuf, M., 2006. Integrating information on marine species identification for fishery purposes. Mar. Ecol. Prog. Ser. 316, 231-238.

Molina, W.F., Shibatta, O.A., Galetti Jr., P.M., 2006. Multivariate morphological analyses in continental and island populations of Abudefduf saxatilis (Linnaeus) (Pomacentridae, Perciformes) of Western Atlantic. Pan Am. J. Aquat. Sci. 1 (2), 49-56.

Morrison, R.A., Sandin, S.A., 2011. Biogeography and population connectivity of coral reef fishes. In: Grillo, O. (Ed.), Changing Diversity in Changing Environment. InTech, Rijeca, pp. 299-322.

MPA, 2012a. Boletim Estatístico da Pesca e Aquicultura-Brasil 2008-2009. 99 pp. http:// www.mpa.gov.br/index.php/monitoramento-e-controle/informacoes-e-estatisticas (Accessed 25 June 2015).

MPA, 2012b. Boletim Estatístico da Pesca e Aquicultura-Brasil 2010.128 pp. http://www. mpa.gov.br/index.php/monitoramento-e-controle/informacoes-e-estatisticas (Accessed 25 June 2015).

MPA, 2012c. Boletim Estatístico da Pesca e Aquicultura-Brasil 2011.60 pp. http://www. mpa.gov.br/index.php/monitoramento-e-controle/informacoes-e-estatisticas (Accessed 25 June 2015).

Nei, M., 1987. Molecular Evolutionary Genetics. Columbia University Press, New York, USA.

Okumuş, I., Çiftci, Y., 2003. Fish population genetics and molecular markers: II- Molecular markers and their applications in fisheries and aquaculture. Turk. J. Fish. Aquat. Sci. 3, 51-79.

Pinheiro, H.T., Joyeux, J.C., Martins, A.S., 2010. Reef fisheries and underwater surveys indicate overfishing of a Brazilian coastal island. Braz. J. Nat. Conserv. 8 (2), 151-159.

Piorski, N.M., Serpa, S.S., Nunes, J.L.S., 2009. Comparative analysis of the fish-weir fisheries at São Luís Island, Maranhão State, Brazil. Arq. Cienc. Mar 42 (1), 1-7.

Planes, S., Doherty, P.J., Bernardi, G., 2001. Strong genetic divergence among populations of a marine fish with limited dispersal, Acanthochromis polyacanthus, within the great barrier reef and the coral sea. Evolution 55, 2263-2273.

Portnoy, D.S., Hollenbeck, C.M., Renshaw, M.A., Portnoy, D.S., Hollenbeck, C.M., Renshaw, M.A., Cummings, N.J., Gold, J.R., 2013. Does mating behaviour affect connectivity in marine fishes? Comparative population genetics of two protogynous groupers (Family Serranidae). Mol. Ecol. 22, 301-313.

Rambaut, A., Suchard, M.A., Xie, D., Drummond, A.J., 2014. Tracer v1.6. Available from. http://beast.bio.ed.ac.uk/Tracer.

Ramires, M., Clauzet, M., Rotundo, M.M., Begossi, A., 2012. Artisanal fishing and fishermen of Ilhabela, São Paulo State, Brazil. Bol. Inst. Pes. São Paulo 38 (3), 231-246.

Rangely, J., Fabré, N.N., Tiburtino, C., Batista, V.S., 2010. Strategies for artisanal fishing in Alagoas Coast, Brazil. Bol. Inst. Pes. São Paulo 36 (4), 263-275.

Ratnasingham, S., Hebert, P.D.N., 2007. BOLD: the Barcode of Life Data System. Mol. Ecol. Notes 7, 355-364 (www.barcodinglife.org)

Reis, A.T., Maia, R.M.C., Silva, C.G., Rabineau, M., Guerra, J.V., Gorini, C., Ayres, A., ArantesOliveira, R, Benabdellouahed, M., Simões, I., Tardin, R, 2013 Origin of step-like and lobate seafloor features along the continental shelf off Rio de Janeiro State, Santos basin-Brazil. Geomorphology 203, 25-45.

Ribeiro, A.D.O., Caires, R.A., Mariguela, T.C., Pereira, L.H.G., Hanner, R., Oliveira, C., 2012. DNA barcodes identify marine fishes of Sao Paulo State, Brazil. Mol. Ecol. Resour. 12 (6), 1012-1020.

Robins, C.R., Ray, G.C., 1986. A Field Guide to Atlantic Coast Fishes of North America. Houghton Mifflin, Boston.

Rocha, L.A., Bowen, B.W., 2008. Speciation in coral-reef fishes. J. Fish Biol. 72, 1101-1121.

Rocha, L.A., Craig, M.T., Bowen, B.W., 2007. Phylogeography and the conservation of coral reef fishes. Coral Reefs 26 (3), 501-512.

Rocha, L.A., Robertson, D.R., Roman, J., Bowen, B.W., 2005. Ecological speciation in tropical reef fishes. Proc. R. Soc. Lond. B Biol. Sci. 272, 573-579.

Rock, J., Costa, F.O., Walker, D.I, North, A.W., Hutchinson, W.F., Carvalho, G.R., 2008. DNA barcodes of fish of the Scotia Sea, Antarctica indicate priority groups for taxonomic and systematic focus. Antarct. Sci. 20, 253-262.

Rogers, A.R., 1995. Genetic evidence for a Pleistocene population explosion. Evolution 49, 608-615.

Rogers, A.R., Harpending, H., 1992. Population growth makes waves in the distribution of pairwise differences. Mol. Biol. Evol. 9, 552-559.

Rossetti, D.F., Polizel, S.P., Cohen, M.C.L., Pessenda, L.C.R., 2015. Late Pleistocene-Holocene evolution of the Doce River delta, southeastern Brazil: implications for the understanding of wave-influenced deltas. Mar. Geol. 367, 171-190.

Santa Brígida, E.L., Cunha, D.B., Rego, P.S., Sampaio, L., Schneider, H., Vallinoto, M., 2007. Population analysis of Scomberomorus cavalla (Curier, 1829) (Perciformes, Scombridae) from the Northern and Northeastern coast of Brazil. Braz. J. Biol. 67 (4), 919-924.

Santos, S., Hrbek, T., Farias, I.P., Schneider, H., Sampaio, I., 2006. Population genetic structuring of the king weakfish, Macrodon ancylodon (Sciaenidae), in Atlantic coastal waters of South America: deep genetic divergence without morphological change. Mol. Ecol. 15 (14), 4361-4373.

Schneider, S., Excoffier, L., 1999. Estimation of past demographic parameters from the distribution of pairwise differences when the mutation rates vary among sites: application to human mitochondrial DNA. Genetics 152, 1079-1089. 
Schunter, C., Carreras-Carbonell, J., Planes, S., Sala, E., Ballesteros, E., Zabala, M., Pascual, M., 2011. Genetic connectivity patterns in an endangered species: the dusky grouper (Epinephelus marginatus). J. Exp. Mar. Biol. Ecol. 401 (1), 126-133.

Silva, R., Veneza, I., Sampaio, I., Araripe, J., Schneider, H., Gomes, G., 2015. High levels of genetic connectivity among populations of yellowtail snapper, Ocyurus chrysurus (Lutjanidae-Perciformes), in the western South Atlantic revealed through multilocus analysis. PLoS ONE 10 (3), e0122173.

Smith, D.E., Harrison, S., Firth, C.R., Jordan, J.T., 2011. The early Holocene sea level rise. Quat. Sci. Rev. 30 (15), 1846-1860.

Souza, A.S.D., Dias Júnior, E.A., Galetti Jr., P.M., Machado, E.G., Pichorim, M., Molina, W.F., 2015. Wide-range genetic connectivity of Coney, Cephalopholis fulva (Epinephelidae), through oceanic islands and continental Brazilian coast. An. Acad. Brasil. Ciênc 87 (1), 121-136.

Stefanni, S., Domingues, V.S., Bouton, N., Santos, R.S., Almada, F., Almada, V., 2006. Phylogeny of the shanny, Lipophrys pholis, from the NE Atlantic using mitochondrial DNA markers. Mol. Phylogenet. Evol. 39, 282-287.

Stepien, C.A., Rosenblatt, R.H., Bargmeyer, B.A., 2001. Phylogeography of the spotted sand bass, Paralabrax maculatofasciatus: divergence of Gulf of California and Pacific coast populations. Evolution 55, 1852-1862.

Tajima, F., 1989. Statistical method for testing the neutral mutation hypothesis by DNA polymorphism. Genetics 123, 585-595.
Tamura, K., Stecher, G., Peterson, D., Filipski, A., Kumar, S., 2013. MEGA6: molecular evolutionary genetics analysis version 6.0. Mol. Biol. Evol. 30, 2725-2729.

Templeton, A.R., Crandall, K.A., Sing, C.F., 1992. A cladistic analysis of phenotypic associations with haplotypes inferred from restriction endonuclease mapping and DNA sequence data. III. Cladogram estimation. Genetics 132, 619-633.

Trushenski, J.T., Rombenso, A., Schwarz, M.H., Bowzer, J., Gause, B., Delbos, B., Sampaio L.A., 2012. Feeding rate and frequency affect growth of juvenile atlantic spadefish. N. Am. J. Aquac. 74, 107-112.

Valdez-Moreno, M., Vásquez-Yeomans, L., Elías-Gutiérrez, M., Ivanova, N.V., Hebert, P.D. 2010. Using DNA barcodes to connect adults and early life stages of marine fishes from the Yucatan Peninsula, Mexico: potential in fisheries management. Mar. Freshw. Res. 61 (6), 655-671.

Ward, R.D., Zemlak, T.S., Innes, B.H., Last, P.R., Hebert, P.D., 2005. DNA barcoding Australia's fish species. Philos. Trans. R. Soc. B 360 (1462), 1847-1857.

Weigt, L.A., Baldwin, C.C., Driskell, A., Smith, D.G., Ormos, A., Reyier, E.A., 2012. Using DNA barcoding to assess Caribbean reef fish biodiversity: expanding taxonomic and geographic coverage. PLoS ONE 7 (7), 41059.

Zhang, J., 2011. Species identification of marine fishes in China with DNA barcoding. Evid. Based Complement. Alternat. Med. 2011, 978253. 